Comparative Philosophy Volume 2, No. 1 (2011): 25-37

Open Access / ISSN 2151-6014

www.comparativephilosophy.org

\title{
COMPARATIVE ASPECTS OF AFRICANA PHILOSOPHY AND THE CONTINENTAL-ANALYTIC DIVIDE
}

\author{
TOMMY L. LOTT
}

\begin{abstract}
Critical engagement involving philosophers trained in continental and analytic traditions often takes its purpose to be a reconciliation of tensions arising from differences in style, or method. Critical engagement in Africana philosophy, however, is rarely focused on method, style, or orientation because philosophic research in this field, regardless of orientation, has had to accommodate its empirical grounding in disciplines outside of philosophy. I focus primarily on the comparative dimensions of three important strands of this research: (1) a history of ideas, (2) a problem-orientation, and (3) a sub-area specialization, to indicate why a need to reconcile tensions between continental and analytic orientations has very little currency in Africana philosophy. Socio-economic problems faced by African-descended people require multiple perspectives to accommodate the wide variety of diasporic social contexts for a given proposal. I employ a selection of cases to illustrate how Africana philosophy benefits from an interplay of many intersecting factors and that, as an interdisciplinary area of research with a commitment to the incorporation of multiple perspectives, it fosters cross-pollination and hybridization of continental and analytic traditions.
\end{abstract}

Keywords: comparative philosophy, Africana, interdisciplinary

Long before Africana Philosophy gained official recognition by the American Philosophical Association as an area of study within the discipline, Western philosophy already had jelled into a rigid divide between continental and analytic schools. (Quinton, 1995) The engagement of continental and analytic philosophers interested in Africana thought suggests a model of how multifarious differences can be negotiated to mutual benefit. Although the term "comparative philosophy" often is based on comparisons between Eastern and Western philosophy, it is also sometimes meant to refer to comparisons between different orientations within these. (Mou, 2010) I consider several dimensions of such comparisons, with special emphasis on the interplay between various modes of philosophical examination and empirical inquiry.

LOTT, TOMMY L.: Professor, Department of Philosophy, San Jose State University, USA. Email: tommy.lott@sjsu.edu 
There are many well-established applied areas in philosophy, such as philosophy of language, education, law, and science, in which philosophical thinking is brought to bear on questions that arise within one of these disciplines. Some areas in philosophy, such as epistemology and aesthetics, have generated theories that have been applied in other applied areas such as philosophy of perception and philosophy of art. I mention these applications of philosophy to other disciplines to point out that the overlap of philosophical concerns with empirical-contingent matters suggests a need to include the latter component (of many areas of philosophy) in the conceptualization of the purpose of a comparison between different traditions. The idea of critical engagement between continental and analytic traditions often takes, as its purpose, a reconciliation of tensions arising from differences in style, or method. In this regard it is important to consider the extent to which interdisciplinary formations such as Marxist Studies, Cultural Studies, Ethnic Studies, Peasant Studies, and Post-colonial Studies have provided a basis for the emergence of new areas in philosophy, such as Africana and Native American philosophy. Given that the need to reconcile tension between continental and analytic orientations has had very little currency in these instances, the term "critical engagement" is somewhat misleading. Critical engagement in Africana philosophy is rarely focused on method, style, or orientation because philosophic research in this field, regardless of orientation, has had to accommodate its empirical grounding in disciplines outside of philosophy. Rather than increasing tensions, this interdisciplinary feature has facilitated coalescence and hybridization of the two schools.

This coalescence is especially noticeable in the attempt, by contemporary philosophers, to articulate philosophical views found in traditional African cultures. Despite strong parallels with Native American philosophy, the suggestion that a philosophic discourse existed in ancient Africa has engendered an extensive debate within African philosophy regarding the definition of philosophy. (Brandt, 1954; Ladd, 1957; Appiah, 1992; Oruka, 1990; Hountondji, 1983) Differences in style, or method, between continental and analytic philosophy, however, have not been an issue in this debate. This is due mainly to the fact that the study of traditional African philosophy has been pursued by Western-trained philosophers, representing both orientations. (Wiredu, 1980; Hallen and Sodipo, 1986; Oruka, 1990)

The study of traditional African philosophy is one of several strands of Africana philosophy engendered by interdisciplinary research that has played an important role as a primary source for the study of Africana thought. I focus primarily on a history of ideas, a problem-orientation, and a sub-area specialization as three important strands. Many topics in Africana philosophy are related to socio-economic problems faced by African-descended people throughout the diaspora, requiring multiple perspectives to accommodate the wide variety of social contexts (that include Latin America and Europe, along with Africa, the United States and the Caribbean) in which a given proposal will have different renderings. I highlight the manner in which Africana philosophy has benefited from the interplay of many intersecting factors. In particular, I indicate how, due to its inherently interdisciplinary nature, Africana philosophy is also inherently pluralistic, and that, as an area within the 
discipline, it came into being as a joint product of cross-pollination of continental and analytic traditions.

The topics I discuss below represent my focus on the three strands I have identified above. They are drawn from African, Afro-Caribbean, and African American philosophy to represent specialists from different sub-areas and to include continental and analytic traditions. In various ways, the selected topics illustrate how insights advanced by continental and analytic philosophers alike have jointly enhanced our understanding of central questions in the field. They also illustrate how the interdisciplinary nature of Africana thought provides a source for philosophical ideas. Whether they are dealing with questions pertaining to language and meaning, ontology and epistemology, or to social and political values, philosophers representing both orientations have been concerned with the formulation of problems, the clarification of key concepts, the generation of pertinent issues, and the assessment of arguments for, or against, various proposals. In the cases I consider, this rather pragmatic concern with practical matters, and the high value placed on the generation of ideas, issues, or insights, that shed light on the question at hand, overrides concerns regarding orientation, method, or style. Discussions of differences in style, method, or orientation have not gained priority over discussions of ideas that advance thinking about a given problem. At this stage of its emergence, ideas and method have pride of place in Africana philosophic research.

I first consider a selection of topics that have been addressed across differences in socio-historical contexts, sub-area specialization, and philosophical orientations to indicate how various subjects have been enhanced by multiple perspectives reflecting these differences. I next consider the role of continental and analytic philosophers in the development of a canon in the field, to show how the development of Africana philosophy has been a joint undertaking. Finally, I turn to consider a turn-of-thecentury, African American philosopher, Alain Locke, to draw attention to the two versions of his dissertation as a methodological paradigm of how to navigate the continental-analytic divide by mastering both styles. The comparative aspects I discuss involve many areas where Africana philosophy overlaps and intersects with other disciplines, as well as with various areas in mainstream and non-Western philosophy. With an eye to these intersections, I indicate the extent to which, in the case of Africana philosophy, critical engagement is multi-faceted.

\section{CROSS-CURRENTS WITHIN AFRICANAN PHILOSOPHY}

Cultural differences associated with geographic location have fostered a discourse in Africana philosophy representing multiple perspectives that aim to shed light on problems shared throughout the African diaspora. As a common source for a history of ideas, continental and analytic philosophers alike have devoted careful scrutiny to views published by ex-slaves, by black abolitionists and emigrationists, by PanAfricanists, and by philosophers concerned with the impact of modernization on traditional aesthetics and cultural values. 
Slave narratives were written by Africans, such as Olaudah Equiano, AfroCaribbeans, such as Mary Prince, and African Americans, such as Frederick Douglass. (Equiano, 1789; Prince, 1831; Douglass, 1848) In each case basic questions regarding human freedom, rights and dignity are raised, yet the predicament of slaves in each sociohistorical context is quite different. These basic questions are taken to be universal and to transcend the different contexts within the diaspora. For this reason, the discussion of slave narratives, and other writings by ex-slaves, in Africana philosophy has included specialists in all three sub-areas representing continental and analytic traditions.

A topic's status as universal is sometimes ambiguous, as when a proposal that has been advanced to deal with a particular problem in a specific context seems to be at odds with what is proposed in a different social context. For example, in his wellknown 1897 address to the Negro Academy on the conservation of races W.E.B. Du Bois introduced the Hegelian notion of double consciousness to argue that African Americans have a duty to retain their cultural identity. (Du Bois, 1897) His view of development and social progress is thoroughly imbued with, and deeply influenced by, a wide reading in continental philosophy. In particular, he displays his background in American pragmatism and German philosophy when he deconstructs the biological notion of race and proposes a reconstruction along the lines of culture.

In his recent book, Tradition and Modernity (1997), Kwame Gyekye argues, in analytic fashion, that individuals in African societies have a duty to transcend their specific cultural identities in support of a national culture. When taken together, the positions advocated by $\mathrm{Du}$ Bois and Gyekye seem to entail mutually exclusive imperatives that are context-specific. Indeed, there seems to be a tension between Du Bois's view that, in the American context of white domination, there is an imperative for African Americans to retain their distinctive Africana culture and Gyekye's view that, in the African context, there is an imperative for members of different ethnic groups to adopt a national culture. The former promotes black pride to counter the negative effects of America's legal segregation, whereas the latter promotes national unity by permiting individuals in African societies to adopt a national identity that transcends having specific ethnic identities. A two-phase account is needed to resolve the seeming inconsistency between these two views of cultural pluralism and social progress. Du Bois and Geyekye are not in disagreement given that, for both, only with the elimination of racial, or ethnic, domination can the option to transcend one's specific ethnic identity be exercised. From the standpoint of the continental-analytic divide this seems to be a case in which the viewpoint of an African American specialist, trained in continental philosophy, is contrary to the viewpoint of an African specialist with an analytic orientation. Notice that each viewpoint is important to consider and that, by contextualizing the problem, both proposals advance our understanding of the issues.

Some apparent differences in doctrine that, perhaps, have been influenced by diaspora location and sociohistorical context, cannot be so easily resolved. These differences are reflected in some of the nineteenth-century debates regarding emigrationism. Although the idea that ex-slaves would have to leave America to gain 
social equality was advocated by African Americans, such as Mary Ann Shadd-Carey and Martin Delany, their views were remarkably different from views held by AfroCaribbean thinkers such as Edwin Blyden and Marcus Garvey. (Delany, 1849; ShaddCarey, 1852; Garvey, 1923) These African American thinkers were less enamored with returning to Africa, often proposing Canada, Mexico and Haiti as possible sites, whereas the Afro-Caribbean thinkers I cite insisted upon a return to Africa as a necessary condition for emigration. Ideological differences of this sort, however, may not be influenced so much by diaspora-location as they are a reflection of the ambivalence prevalent throughout the diaspora towards Africa as a homeland for descendants.

For many reasons, the much-contested African-centered nationalism in Africana thought displays the influence of sociohistorical context. Toward the end of the nineteenth century, at the height of colonialism in Africa, some version of panAfricanism was widely supported by a vast majority of black intellectuals throughout the diaspora. Despite the popularity of Marcus Garvey in the 1920s, in post-colonial Africa, with the exception of Kwame Nkrumah in Ghana, it was never widely embraced by African heads of state. Representing a line of thought that is specific to the African American context, Tommie Shelby has proposed to replace the notion of an African-centered cultural nationalism with a notion of black solidarity that he maintains is more pragmatic for African Americans. (Shelby, 2005) His revised notion is suited to focus strictly on ending antiblack racism in America without a commitment to maintaining Africana cultures. Although disagreement among philosophers on issues pertaining to nationalism and culture is, undoubtedly, influenced by many factors, sociohistorical context is often a determinant. While a proponent's philosophic orientation is relevant to understanding her method of arriving at a certain position, as well as her grounds for maintaining it, cross-currents involving these orientations have combined with other factors to generate new lines of thought that yield new insights, and new debates.

\section{SHAPING THE CANON: CROSS-POLLINATING CONTINENTAL AND ANALYTIC TRADITIONSS}

Some of the cross-currents that give rise to multiple perspectives on topics shared throughout the diaspora also have contributed to the establishment of a canon that includes classic texts commonly referenced by philosophers interested in a thinker's ideas, or in a particular subject. The examples I cite below involve the treatment of a subject from multiple perspectives by sub-area specialists and the interpretation of a thinker's ideas by philosophers representing both traditions.

Questions regarding the moral and political grounds of slavery and colonialism have been a source of philosophical reflection in Western philosophy since the time of the Greeks. (Williams, 1993) In Africana philosophy, a critical examination of these subjects has been undertaken by continental and analytic philosophers throughout the diaspora. Almost everyone versed in Africana thought is familiar with C.L.R. James's classic social and political account of the Haitian revolution in The 
Black Jacobins (1938). Hardly anyone knows, however, that it was presaged by Anna Julia Cooper's lesser known French-language doctoral dissertation in 1925. Cooper was an ex-slave who earned her undergraduate degree at Oberlin in 1887 and her doctorate at the Sorbonne in 1925. She is better-known for her classic feminist text, $A$ Voice From the South (1892). James was a Marxist historian, well-known for his theoretical writings in political theory, especially his unpublished Notes on Dialectics (1948) and his masterpiece in social history, Beyond A Boundary (1963). Cooper's analysis of the Haitian revolution relies on French Enlightenment philosophy to account for the ideological grounding of slave resistance, whereas James's Marxist analysis casts a skeptical glance at that tradition. Along with a comparison of an African-American female ex-slave viewpoint with an Afro-Caribbean Marxist male viewpoint as a complex set of factors influencing the respective accounts, in this case, multiple perspectives also include - as a factor equally influencing their views - the Anglophone context for James's book and the Francophone context for Cooper's dissertation. Whichever factors we choose to account for differences in their respective analyses notwithstanding, these two philosophers represent interdisciplinary thinkers, each with a strong background in continental philosophy, who have advanced our thinking about a central topic in Africana philosophy.

Frantz Fanon's Wretched of the Earth is another classic text in Africana philosophy. In Fanon and the Crisis of European Man (1995), Lewis Gordon, an Afro-Caribbean specialist, employs his training in continental philosophy, specifically Husserl's phenomenology, to interpret Fanon's thought. Analytic philosophers, such as Bernard Boxill, have also presented interpretations of Fanon's text. Boxill, a specialist in African American philosophy, extracts a line of reasoning from Wretched of the Earth to spell out a moral argument regarding protest and self-respect. (Boxill, 1976) A quite different reading is presented by Nigerian philosopher, Oladipo Fashina. He presents a logically rigorous version of an argument in Fanon's text that represents a non-humanistic line of thought. (Fashina, 1989) In this case, philosophers representing multiple perspectives, and trained in both traditions, have reflected upon a classic work in continental philosophy by a Francophone AfroCaribbean philosopher, and have arrived at quite different interpretations.

\section{ALAIN LOCKE'S DISSERTATION ON VALUES: MERGING CONTINENTAL AND ANALYTIC TRADITIONS}

Around the turn of the century, before the rise of logical positivism and the influence of the Vienna Circle on Anglo-American philosophers, W.E.B. Du Bois and Alain Locke were studying at European universities. (Quinton, 1995) While at Harvard both were students of the well-known American pragmatist, William James. Pragmatism, as a school of thought associated with American philosophers influenced by Charles Peirce, John Dewey, as well as James, has broadly appealed to continental and analytic philosophers alike. James stands out, with his experimental research in psychology, as an interdisciplinary thinker. In turn, James, an empirical scientist, was influenced by French philosopher, Henri Bergson. The reason for James's high 
regard in both traditions, however, was not his scientific, or continental, leanings. Rather, his broad appeal is due more to his influence on two of the twentiethcentury's greatest philosophers - Edmund Husserl and Ludwig Wittgenstein. Research in Africana philosophy on two of James's students, Du Bois and Locke, reflects these historical traces of American Pragmatism on continental and analytic traditions.

As a Rhodes scholar at Oxford Locke wrote a dissertation on value theory that displayed the influence of James' teachings regarding the centrality of experience. Other than James, almost all of his sources were early twentieth-century continental philosophers, including Franz Brentano and Alexius Meinong. He mailed his dissertation to Oxford from Berlin, where he actually had written it during the spring and summer of 1910. Having begun coursework toward earning a doctorate at the University of Berlin, he attended the lectures of many distinguished German philosophers, including Georg Simmel, and Ernst Cassirer. (Harris and Molesworth, 2008) Locke's thesis was not accepted for several reasons. Most notable was his misfortune of having the logician, J. Cook Wilson, assigned to read it. When financial concerns became paramount, and Locke was unable to complete his doctorate at the University of Berlin, he accepted a teaching position at Howard University in Washington, D.C.

Several years later, in 1917, he wrote another version of his Oxford thesis to satisfy requirements for a doctorate at Harvard. As an undergraduate at Harvard (and later at the University of Berlin) he had studied with Hugo Meunsterber. Another of his undergraduate teachers, Ralph Barton Perry, a specialist working in value theory, was his thesis advisor. Needless to say, Perry was much more suitable to read Locke's dissertation - especially so, given Locke's psychological focus on valuation. In the Harvard dissertation, Locke transformed his original tome, "A Genetic Theory of Value", which was lucidly written in a continental style, into a somewhat less ambitious analytic project, "A Classification of Values." What is important to note here is that, he learned from his experience with Cook at Oxford how better to negotiate his decidedly continental orientation with Perry's analytic leanings. The second version of his dissertation was a hybrid of continental and analytic philosophy.

Given the hegemony of analytic philosophers in many departments, as well as throughout the professional organizations, the practice of recasting insights derived from continental philosophy into an analytic mode of discourse is a familiar means of negotiating the continental-analytic divide. While most philosophers interested in Africana thought are trained specifically in one of the two traditions, the audience for their work represents both orientations. The fact that many of the major Africana philosophers, such as Cooper, Du Bois, Locke, James, and Fanon, represent the continental tradition is an advantage for continental philosophers and indirectly fosters pluralism in the study of Africana philosophy. The merit of this inherent tendency toward pluralism cannot be overstated. For, an important lesson to be garnered from the two versions of Locke's dissertation on values is that, on this particular subject, a wholly analytic, or continental, treatment is inadequate. 
Locke's project on values was directly related to his later writings on aesthetics, art and music, for which he is much better known. In his self-proclaimed role as "mid-wife" to the Harlem Renaissance writers and artists he is acknowledged by Amie Cesaire and Leopold Senghor to have inspired the Negritude movement. (Kennedy, 1972; Senghor, 1977) Although this movement originated in the American context, it gained momentum mostly in Francophone regions of the Caribbean and Africa. Many questions regarding aesthetics are culturally specific. However, in the case of Negritude, differences in cultural values, influenced by socio-historical context, did not hinder proponents from claiming a cross-cultural application of their ideas throughout the diaspora. It is noteworthy that, although topics related to Negritude also raise important issues of great interest to analytic philosophers, even in its earliest American stage during the Harlem Renaissance, the movement was an interdisciplinary project involving philosophers who were grounded mainly in continental philosophy. (Sartre, 1948; Senghor, 1977; Bernasconi, 2001)

\section{CRITICAL ENGAGEMENT AND INTERDISCIPLINARY CONCERNS}

The need for critical engagement to bridge the continental-analytic divide is fairly non-existent in the case of Africana philosophy because often the two styles are immersed in cross-dialogue with a focus on the question at hand - rendering concerns about orientation, or style, less important. In addition to this pragmatic factor, I want to suggest a more fundamental reason having to do with the interdisciplinary nature of Africana philosophy. With a focus on some of the major strands of Africana philosophy, I have already cited above examples of critical engagement involving exchanges between philosophers representing both orientations and specialization in the sub-areas. I have also cited examples of critical engagement involving exchanges between philosophers within each of the two schools regarding the interpretation of a classic text. I will conclude with a consideration of intersections with various disciplines to acknowledge comparative aspects of Africana philosophy that involve overlap with interdisciplinary studies, e.g., Ethnic, Post-colonial, or Women's Studies; with other areas of Western philosophy, e.g., Marxism, Latin American, or feminism; or with Non-Western philosophy, e.g., Asian, or Native American.

The relation of Africana philosophy to other disciplines indicates a structural basis for the cross-dialogue between continental and analytic philosophers. The empirical circumstances of African people throughout the diaspora accounts for the social and political focus-specifically on socioeconomic problems-in Africana philosophy. Various disciplines in the social sciences, along with history, literature, art, and music are best suited to study and establish a body of empirical knowledge regarding these contingent matters. Africana philosophy draws upon all of these disciplines, but so do other categories of interdisciplinary studies, such as Women's, Ethnic, Cultural, and Post-colonial Studies. Indeed, many subjects in Africana philosophy often have been topics of prior debates in Africana thought generally, or subjects previously discussed in related disciplines. In this important respect Africana philosophy overlaps other disciplines and is inherently interdisciplinary. 
There is a great deal of research, pursued in other disciplines, that involves a critical examination of issues pertaining to racism, slavery, and colonial oppression. Just as scholars in those disciplines have not established an exclusive claim on these subjects, neither have philosophers who address issues of specific concern to philosophers, for empirical findings that have a bearing on their philosophic concerns cannot be ignored. For this reason, debates and exchanges within Africana philosophy are not limited to the multiple perspectives influenced by, and reflecting, sociohistorical context, area of specialization and continental-analytic orientation. On many topics such as race, affirmative action, criminal justice, punishment, health care, welfare rights and reparations, Africana philosophy also critically engages many mainstream philosophic concerns related to policy.

This engagement can, in some cases, be a direct challenge to a view that is wellregarded in mainstream philosophy. An example of this would be Kawasi Wiredu's appeal to the conceptualization of truth in his native Akan language to question whether Alfred Tarski's semantic theory of truth is universal. (Wiredu, 1980) Unlike this philosophy of language case, involving a well-known philosopher's theory of truth, more often this engagement is in the manner of applied philosophy. In these latter cases some subject outside of philosophy is critically examined by philosophers. For example, social scientists, such as Orlando Patterson and historians such as Eugene Genovese have been challenged by philosophers on their views of the injustice of slavery. (Lott, 1998; Mc Gary, 1992) Relying on liberal democratic notions of paternalism and social justice, philosophers have raised questions regarding the social and political implications of empirical accounts by social scientists and historians.

In certain instances of mainstream-Africana engagement, philosophers employ the views of historical European philosophers to interpret an Africana thinker, or text. Sometimes the aim is to establish a direct parallel. This strategy is employed by Jill Gordon in her comparative analysis of Malcom X's "Ballot or the Bullet" speech and John Locke's teachings on resistance in the Second Treatise. (Gordon, 1995) It is also employed by Julie Ward in her comparative analysis of arguments against slavery by Olaudah Equiano and Ottobah Cugoano in which she traces many of their ideas to views expressed in the writings of specific European Enlightenment thinkers such as Granville Sharp, Thomas Clarkson, and James Ramsay. (Ward, 1998)

Sometimes the aim of Africana-mainstream critical engagement is to appropriate and employ an argument, or line of reasoning, that can be found in a European philosopher's text. In her lecture on Douglass's slave narrative, Angela Davis employs Hegel's master-slave parable to interpret the shift in Douglass' consciousness that motivated his quest for freedom. (Harris, 1983) In a similar fashion, Bernard Boxill develops an argument for reparations based on John Locke's view in the Second Treatise. (Boxill, 2003) What should be noted here is that Davis's continental orientation and Boxill's analytic style are equally important modes of arriving at insights that shed light, respectively, on Douglass's text and the subject of reparations. 
The comparative aspects of Africana philosophy I have cited indicate the extent to which continental and analytic traditions have been equally important to the growth and development of this emerging field. No special claim is being made for Africana philosophy in this regard, for other areas within the discipline may also represent similar contributions by representatives of both traditions. The domination of analytic philosophy by logical positivism and linguistics and continental philosophy by phenomenology and hermeneutics is reminiscent of tensions between rationalists and empiricists in modern philosophy resulting from their different views of the role of reason and sense perception in epistemology. What has gone unremarked in both cases is the extent to which the respective views bleed into each other, resulting in hybridization on both sides. Whether this bleeding process entitles us to speak of a "merging" of the two traditions is an empirical question to be decided by future developments within the field.

\section{ACKNOWLEDGEMENTS}

I am grateful to my three anonymous reviewers for valuable comments and criticisms.

\section{REFERENCES}

Appiah, Anthony (1992), In My Father's House: Africa in the Philosophy of Culture (New York: Oxford University Press).

Boxill, Bernard R. (2003), "The Morality of Reparations II", in Tommy L. Lott and John P. Pittman (eds.), A Blackwell Companion to African-American Philosophy (Malden, MA: Blackwell Publishers), pp. 134-54.

Boxill, Bernard R. (1992), Blacks and Social Justice Revised Edition (Lanham, MD: Rowman \& Littlefield).

Boxill, Bernard R. (1976), "Self-Respect and Protest", Philosophy \& Public Affairs 6: 58-69.

Brandt, Richard (1954), Hopi Ethics (Chicago: University of Chicago Press).

Carey, Mary Ann Shadd (1852), A Plea for Emigration, or Notes of Canada West (Detroit: G.W. Pattison).

Cooper, Anna Julia (1892), A Voice From the South (Xenia, OH: The Aldine Printing House).

Cooper, Anna Julia (1925), L'Attitude de la France à l'égard de l'esclavage pendant la Révolution (Sorbonne, Ph.D. Thesis), translated by Frances Richardson Keller in (1988), Slavery and the French and Haitian Revolution (Lewiston, N.Y.: Mellen Press).

Cugano, Ottobah (1789), Thoughts and Sentiments on the Evils of Slavery (London).

Delany, Martin R. (1849), The Condition, Elevation, Emigration, and Destiny of the Colored People of the United States (Wilmington, DE: n.p.) 
Douglass, Frederick (1848), Narrative of the Life of A Slave, in Narratives of Mary Prince, Frederick Douglass and Harriet Jacobs, ed. H.L. Gates (New York: N.A.L. Penguin; 1987).

Du Bois, W.E.B. (1897), “Conservation of Races", Occasional Papers, No. 2 American Negro Academy.

Du Bois, W.E.B. (1895), "Sociology Hesitant", in Ronald T. Judy (ed.), boundary 2 27.3 Special Edition, pp. 37-44.

Equiano, Olaudah (1789), The Interesting Narrative of the Life of Olaudah Equiano, in Narratives of Mary Prince, Frederick Douglass and Harriet Jacobs, ed. H.L. Gates (New York: N.A.L. Penguin; 1987).

Fanon, Frantz (1963), The Wretched of the Earth (New York: Grove Press).

Fashina, Oladipo (1989), "Frantz Fanon and the Ethical Justification of Anti-Colonial Violence", Social Theory and Practice 5.2: 179-212.

Genovese, Eugene D. (1974), Roll, Jordon, Roll: The World the Slaves Made (New York: Pantheon).

Garvey, Amy Jacques (ed.) (1923), Philosophy and Opinions of Marcus Garvey (New York: Universal Publishing House).

Gordon, Jill (1995), "By Any Means necessary John Locke and Malcolm X on the Right to Revolution", Journal of Social Philosophy 26.1 (Spring): 53-85.

Gordon, Lewis (1995), Frantz Fanon and the Crisis of European Man: An Essay on Philosophy and the Human Sciences (New York: Routledge).

Gordon, Lewis (ed.) (1997), Existence in Black (New York: Routledge).

Gyekeye, Kwame (1997), Tradition and Modernity: Philosophical Reflections on the African Experience (New York: Oxford University Press).

Hallen, Barry and J.O. Sodipo (eds.) (1986), Knowledge, Belief, and Witchcraft (London: Ethnographica Press).

Harding, Sandra and Uma Narayan (eds.) (2000), Science and Other Cultures: Issues in Philosophies of Science and Technology (Bloomington: Indiana University Press).

Harris, Leonard and Charles Molesworth (2008), Alain L. Locke: The Biography of a Philosopher (Chicago: University of Chicago Press).

Harris, Leonard (1999), The Critical Pragmatism of Alain Locke (Lanham, MD: Rowman \& Littlefield).

Harris, Leonard (ed.) (1983), Philosophy Born of Struggle: Anthology of AfroAmerican Philosophy from 1917 (Dubuque, IA: Kendall/Hunt).

Henry, Paget (2000), Caliban's Reason: Introducing Afro-Caribbean Philosophy (New York: Routledge).

Hountondji, Paulin J. (1983), African Philosophy: Myth and Reality (Bloomington: Indiana University Press).

James, C.L.R. (1935), The Black Jacobins (3d ed. 1980) (London: Allison and Busby).

James, C.L.R. (1963), Beyond A Boundary (reprint 1993) (Durham: Duke University Press). 
James, C.L.R. (1948), Notes on Dialectics: Hegel, Marx, Lenin (reprint 2006) (London: Pluto Press).

Kennedy, Ellen C. (1972), "An Interview with an Architect of Negritude: Cesaire”, in W.H. Robinson (ed.), Nommo (New York: Macmillan), pp. 30-37.

Ladd, John (1957), The Structure of A Moral Code: A Philosophical Analysis of Ethical Discourse Applied to the Ethics of the Navaho Indians (Cambridge, MA: Harvard University Press).

Locke, Alain L. (1925), The New Negro (New York: Albert and Charles Boni).

Lott, Tommy L. (1998), "Early Enlightenment Conceptions of Slavery", in his Subjugation and Bondage (Lanham, MD: Rowman \& Littlefield), pp. 99-129.

McGary, Howard and Bill E. Lawson (1992), Between Slavery and Freedom: Philosophy and American Slavery (Bloomington, IN: Indiana University Press).

Mosley, Albert G. (1995), "Negritude, Nationalism, and Nativism: Racists or Racialists?" in his anthology African Philosophy: Selected Readings (PrenticeHall), pp. 216-35.

Mou, Bo (2010), "On Constructive-Engagement Strategy of Comparative Philosophy: A Journal Theme Introduction", Comparative Philosophy 1.1: 1-32 <http://www.comparativephilosophy.org>.

Nkrumah, Kwame (1964). Consciencism. (London: Heinemann).

Nkrumah, Kwame (1970), Class Struggle in Africa. (International Publishers).

Oruka, H. Odera (1990), Sage Philosophy: Indigenous Thinkers and Modern Debate on African Philosophy (Leiden: Brill).

Prince, Mary (1831), The History of Mary Prince, a West Indian Slave. Related by Herself (3d ed.) (London: F. Westley and A.H. Davis, Stationers' Hall Court).

Patterson, Orlando (1982), Slavery and Social Death (Cambridge, MA: Harvard University Press).

Quinton, A. (1995), "Analytic Philosophy" and "Continental Philosophy", in Ted Honderich (ed.) The Oxford Companion to Philosophy (Oxford: Oxford University Press), pp. 28-30 and 161-63.

Sartre, Jean Paul. (1948), "Orphée noir" in Situations III (Paris: Gallimard), English translation by Samuel Allen (1962), Black Orpheus (Paris: Présence Africaine).

Shadd-Carey, Mary Ann (1852), A Plea for Emigration, or Notes of Canada West (Detroit: G.W. Pattison).

Senghor, Leopold S. (1964), On African Socialism, translated by Mercer Cook (New York: Praeger).

Senghor, Leopold S. (1977), "Negritude and Modernity or Negritude as a Humanism for the Twentieth Century", in Robert Bernasconi (ed.) (2001), Race (Malden, MA: Blackwell Publishers), pp. 143-65.

Shelby, Tommy (2005), We Who Are Dark: The Philosophical Foundations of Black Solidarity (Cambridge, MA: Harvard University Press).

Ward, Julie (1998), "The Master's Tools: Abolitionist Arguments of Equiano and Cugoano", in Tommy L. Lott (ed.), Subjugation and Bondage: Critical Essays on Slavery and Social Philosophy (Lanham, MD: Rowman \& Littlefield), pp. 79-98. 
West, Cornel (1989), The American Evasion of Philosophy: A Genealogy of Pragmatism (Madison: University of Wisconsin).

Williams, Bernard (1993), Shame and Necessity (Berkeley: University of California Press).

Wiredu, Kwasi (1980), Philosophy and an African Culture (Cambridge: Cambridge University Press).

Wiredu, Kwasi (1996), Cultural Universals and Particulars: An African Perspective (Bloomington, IN: Indiana University Press). 